\title{
Study of Failure Mode and Effect Analysis (FMEA) on Capacitor Bank Used in Distribution Power Systems
}

\author{
A. Pourramazan ${ }^{1}$, S. Saffari ${ }^{2}$, A. Barghandan ${ }^{3}$ \\ Monenco Consulting Engineers, Tehran, Iran ${ }^{1,2,3}$
}

\begin{abstract}
Failure Mode and Effect Analysis (FMEA) is the systematic procedure for the analysis and assessment of the potential failure of the equipment. Failure modes of the equipment, causes and effects of the failure modes, detection methods and mitigation methods, as well as the severity of the effects and frequency are specified in the FMEA. This study is a part of the project "consultancy services for preparation of network asset maintenance standards \& associated asset management documentation" which are carried out by Monenco consulting engineering company (Iran) for Majan Electricity Company SAOC (Oman). This paper presents FMEA and related worksheets for capacitor banks used in Oman distribution power system and consist of following items: component of the equipment, functions of the component, failure modes of the component, failure causes, failure effect (local and final), detection method, compensating provision, severity of the effect and eventually frequency of the failure modes. This method can be utilized for FMEA execution of all other equipment of the power distribution system. The output of the FMEA can be utilized for critically analysis, Reliability centered maintenance (RCM) and risk based maintenance initiatives.
\end{abstract}

Keywords: Failure Mode and Effect Analysis, FMEA, Asset Management, capacitor bank.

\section{INTRODUCTION}

Asset Management is a systematic and coordinated the management of the whole of the corporation/ activities and practices through which an organization organization. This paper describes some tools, methods optimally and sustainably manages its assets and asset and activities, which can be utilized as asset management systems, their associated performance, risks and in the lowest level of the figure 1 i.e. managing assets and expenditures over their life cycles for achieving its equipment of the power system. According to this figure, organizational strategic plan [1].

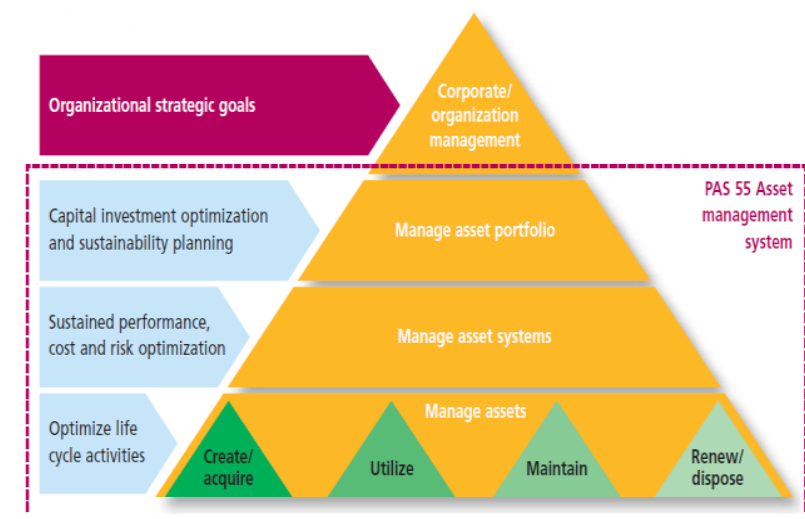

Fig. 1. Various levels of implementing asset management [1]

Referring to figure 1, asset management can be utilized in four stages. In the lowest one, management of the equipment of the power system is considered. Optimizing the life cycle activities of the equipment is the objective of this level. Two upper levels i.e. manage asset systems and manage asset portfolio, are for the management of the entire of the power grid. The upper level is associated with life cycle of the asset consists of four stages: Createacquire, Utilize, Maintain, and Renew/dispose. Some tools and methods can be utilized for the best implementing of the asset management program in its life cycle, such as Failure Mode and Effect Analysis, Health Index Calculation, Maintenance Standard Documentation and Asset mission document. In this paper, only Failure Mode and Effect Analysis will be studied.

Failure Modes and Effect Analysis (FMEA) is a systematic procedure for the analysis of a system to identify the potential failure modes, their causes and effects on system performance.

FMEA implementation is based on the "British Standard 60812:2006" [2]. Failure mode, causes, effects, detection method, mitigation method and severity are defined in table I. A work sheet (table V) is provided for capacitor banks according to table I and the remainder of this paper illustrates each column of this table.

\section{EQUIPMENT COMPONENT \& FUNCTIONS}

The increasing adoption of power electronic converters such as in electric drives [3], [4] generate current harmonics which may even affect the local marginal prices 


\section{ISO 3297:2007 Certified}

Vol. 5, Issue 2, February 2017

in transmission level [5] or change the security unit is the building block of any shunt capacitor bank. The characteristics of the networks such as islanding detection capacitor unit is made up of individual capacitor elements, when synchronous generators are enhanced [6]. Capacitor arranged in parallel/series connected groups. Each Banks are installed to provide capacitive reactive capacitor element is an insulated foil capacitor which is compensation and power factor correction. A capacitor insulated with a solid insulation film and insulating liquid.

TABLE I FMEA WORKSHEET WITH RELATIVE DEFINITIONS

\begin{tabular}{|c|c|c|c|c|c|c|c|c|}
\hline \multirow{2}{*}{ 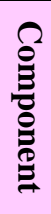 } & \multirow[b]{2}{*}{ 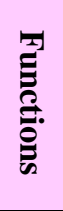 } & \multirow[b]{2}{*}{$\begin{array}{c}\text { Failure } \\
\text { modes }\end{array}$} & \multirow[b]{2}{*}{$\begin{array}{l}\text { Failure } \\
\text { causes }\end{array}$} & \multicolumn{2}{|c|}{ Failure effect } & \multirow[b]{2}{*}{$\begin{array}{c}\text { Detection } \\
\text { method }\end{array}$} & \multirow{2}{*}{ 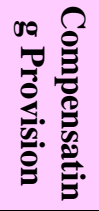 } & \multirow[b]{2}{*}{$\underset{\mathscr{Q}}{\mathscr{Q}}$} \\
\hline & & & & Local Effect & Final Effect & & & \\
\hline \multirow{2}{*}{ 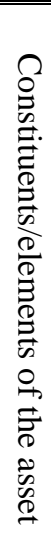 } & \multirow{2}{*}{ 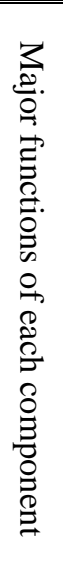 } & \multirow{2}{*}{ 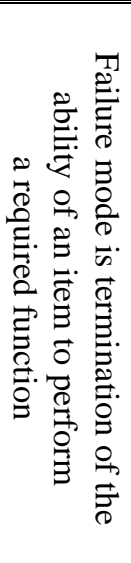 } & \multirow{2}{*}{ 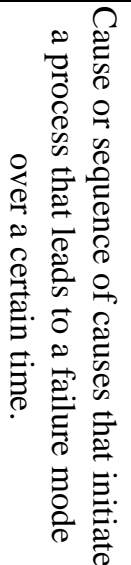 } & \multicolumn{2}{|c|}{$\begin{array}{l}\text { Consequence of a failure mode in } \\
\text { terms of the operation, function, } \\
\text { or status of a system. }\end{array}$} & \multirow{2}{*}{ 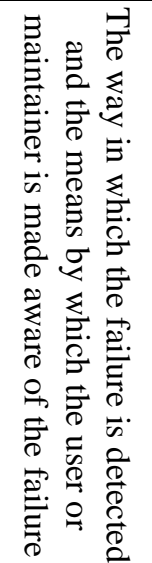 } & \multirow{2}{*}{ 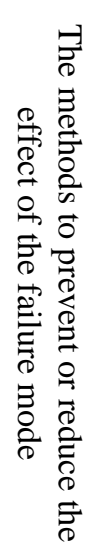 } & \multirow{2}{*}{ 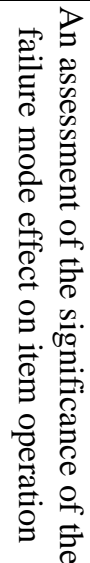 } \\
\hline & & & & 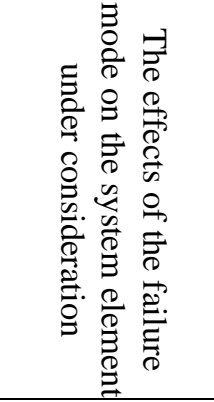 & 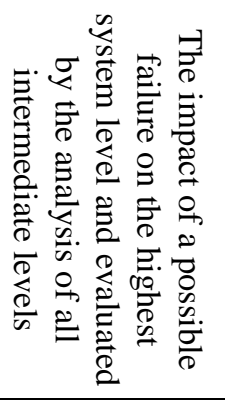 & & & \\
\hline
\end{tabular}

In addition, there are internal discharge resistors in the unit Upon the capacitor failure, the fuse removes the affected that reduces the unit residual voltage and allowing element only. The other elements, connected in parallel in switching the banks back after removing it from service. the same group, remain in service but with a slightly Figure 2 shows that a capacitor unit is contained within a higher voltage across them. Shunt capacitor banks usually metal container and connected to two voltage insulated consist of multiple units in series, which are connected as bushings for external connections. double star ungrounded. Capacitor banks are metal-clad in In Oman distribution grid, always internally fused Oman distribution grid. Other component of the capacitor capacitor bank is used. It means that, each capacitor banks are support insulators and interconnecting fuses. element is fused inside the capacitor unit. A simplified fuse is a piece of wire sized to melt under the fault current, and encapsulated in a wrapper able to withstand the heat produced by the arc during the current interruption (Figure 2).

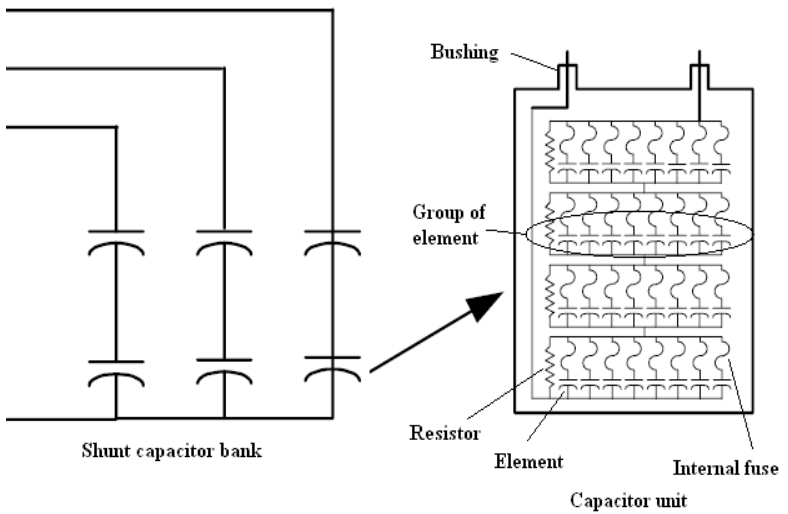

Fig. 2. Capacitor Unit

\section{III.FAILURES, CAUSE AND EFFECT OF THE FAILURES}

Some major failure modes of capacitor banks are introduced as following [7]-[9].

A. Capacitor Element Short Circuit

Each capacitor element is an insulated foil capacitor which is insulated with a solid insulation film and insulating liquid. The failure mode of the capacitor element is an insulation film failure across the element foil capacitors and shorting the foil. Most of these failures are due to some cavities inside the solid insulation film that result in partial discharges in the insulation [10]. After failure, relative fuse removes the affected element only. The other elements, connected in parallel in the same group, remain in service but with a slightly higher voltage across them. Usually the unbalance relay that measure the neutral point current of the capacitor bank, doesn't trip by one element 
Vol. 5, Issue 2, February 2017

short circuit, But if some other elements will be shorted, I. Electrical Flashover of Support Insulators unbalance relay will trip the capacitor bank (depending on If the surrounding air is ionized/contaminated or the unbalance relay setting). electrical over voltages are very high, flash over across the insulator and between phases can occur, which lead to

\section{B. Open Circuit}

Disconnection of any interconnecting wires in the capacitor unit results to change in capacitance and probability to unbalance relay trip.

\section{Insulating Liquid Leakage}

Wearing of metal enclosure of the unit, any gap or seam of the enclosure can results in insulating liquid leakage.

\section{Bushing Degradation}

Bushing degradation of unit include cracking, wear, contamination, etc. can be occurred due to external contamination, moisture, insulation failure, flash over, short circuit, probability of explosion and fire.

\section{E. Fuse Failure}

Fuse degradation results primarily from the failure of seals and ingress of moisture, or environment high temperature. In short circuit situation of a capacitor element, if relative fuse is not operated, all elements in parallel in same group will be shorted. The remaining series capacitor elements in the unit remain in service with a higher voltage across each of them. It changes the capacitance value and can result in tripping unbalance relay. On the other hand, if a fuse is blown in normal condition (no short circuit), the capacitor element will be opened and results in changing the capacitance value and probability of tripping unbalance relay (depending on unbalance relay setting but usually does not trip by one fuse mal-operation).

\section{F. Thermal Stresses}

Thermal stresses are due to high temperature gradient $[11$, 12]. Environment high temperature results in degradation of insulation in capacitor units and external insulators.

\section{G. Electrical Stresses}

During service, capacitor banks experience steady state, transient and dynamic over-voltage conditions (for example connecting the capacitor bank to grid when load is low, can result in overvoltage of capacitor bank).

Switching devices that re-strike during de-energizing impose additional stress on capacitors. Such stress results in cumulative and non-reversible degradation of insulation in capacitor units and external insulators. Degradation rates depend on design, safety margins, system conditions and environmental factors. The electrical surges could have detrimental effects on the capacitors structure [13]

H. Fail to Provide Safety in Operation

There is some interlock for correct operation of capacitor banks. If these interlock fails due to disconnecting any DC supply, wires, defect of auxiliary relay, etc., it could result to hazards for personnel or capacitor bank. short circuit. Such internal arcs can increase the pressure inside the capacitor panel and cause its burst, which can be dangerous for operators.

J. Leakage current for support insulators

Contamination and tracks over the insulator surface will cause to leakage current.

K. Thermal and electrical forces for support insulators

Short circuit currents will produce high forces that act on the insulators. In rare cases, ultra-high forces can cause failure of the insulator. However there are a few methods that can limit the amount of fault current with help of PTC devices [14].

In addition, following failure modes maybe occurred for panel of the capacitor bank.

- Misaligned and failure of mounting

- Degradation of panel body plate (Corrosion, damage, fatigue, rust spots, graffiti, scratch, etc.)

- Failure of protection degree of panel (IP)

- Failure of lighting / heater / thermostat of panel

- Failure of door to operate properly (open, close, lock)

- Disconnection of electrical connections and/or wiring

Specifications of above panel failure mode are specified in worksheet (See table V). Capacitor structure affects the damage development caused by any current flashover [1516].

\section{IV.DETECTION METHODS \&FAILURE COMPENSATION PROVISIONS}

The detection method for each failure mode is the way in which the failure is detected and the means by which the user or maintainer is made aware of the failure. Condition monitoring activities/detection methods are specified in the worksheet (table V). In addition to the traditional detection methods, novel non-destructive testing and Evaluation (NDT\&E) techniques [17] are recently introduced such as wave propagation based SHM can be employed to detect possible damages in panel body plate [18-19].

Compensation provisions are activities that prevent or reduce the effect of failure mode. These provisions are specified in the worksheet (table V).

\section{SEVERITY CLASSIFICATION}

Severity is an assessment of the significance of the failure effects (final effect) on system operation and personal safety. Severity of each failure modes is specified in the worksheet (table V) based on table II and classified to four levels; Catastrophic, Critical, Marginal and Insignificant. 
Vol. 5, Issue 2, February 2017

\section{VI.CONCLUSION}

Capacitor banks are used in distribution networks extensively and records of Majan Electricity Company SAOC (Oman) show that some of Medium Voltage grid outage is related to capacitor banks. In the first step of this paper, capacitor bank components and functions were described. Then failure modes comprising short-circuit, open circuit, Insulating liquid leakage, Fuse failure, etc and their effects on the system operation and personal safety were explained. After that, detection methods for each failure mechanism and compensating provisions to prevent or reduce the effects of each failure were mentioned to summarize in the worksheet (table V). Then, failure mechanisms were classified in accordance with their severity. Finally, one worksheet that included all items described in this paper is produced and developed for capacitor banks used in Oman Distribution Power System. (See table V)

It must be mentioned that the output of the FMEA can be utilized for FMECA (Failure mode, effect and critically analysis). In this regard, a RPN (Risk Priority Number) is dedicated to each failure mode.

$\mathrm{RPN}=$ Value of (Severity) $*$ Value of (Occurrence) $)^{*}$ Value of (Detection)

where value of Severity is obtained based on the table II and value of detection and occurrence are obtained based on the following tables.

The output of the FMEA and FMECA is suitable to support RCM (Reliability Centered Maintenance) and Risk Basked Maintenance initiatives.

\section{TABLE III SEVERITY QUALITATIVE CLASSIFICATION}

\begin{tabular}{|c|c|c|}
\hline Class & 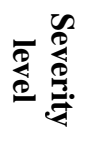 & Criteria \\
\hline IV & 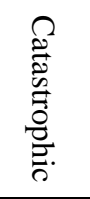 & $\begin{array}{l}\text { A failure mode which could potentially } \\
\text { result in the failure of the system's } \\
\text { primary functions and therefore causes } \\
\text { serious damage to the system and its } \\
\text { environment and/or personal injury. }\end{array}$ \\
\hline III & $\begin{array}{l}\Omega \\
\stackrel{\Xi}{\mathscr{B}} \\
\stackrel{0}{0}\end{array}$ & $\begin{array}{l}\text { A failure mode which could potentially } \\
\text { result in the failure of the system's } \\
\text { primary functions and therefore causes } \\
\text { considerable damage to the system and its } \\
\text { environment, but which does not } \\
\text { constitute a serious threat to life or injury. }\end{array}$ \\
\hline II & 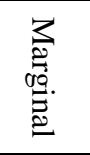 & $\begin{array}{l}\text { A failure mode, which could potentially } \\
\text { degrade system performance, function(s) } \\
\text { without appreciable damage to system or } \\
\text { threat to life or injury. }\end{array}$ \\
\hline I & 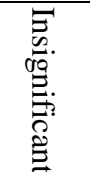 & $\begin{array}{l}\text { A failure mode, which could potentially } \\
\text { degrade the system's functions but will } \\
\text { cause no damage to the system and does } \\
\text { not constitute a threat to life or injury. }\end{array}$ \\
\hline
\end{tabular}

TABLE IIIII FREQUENCY QUALITATIVE CLASSIFICATION

\begin{tabular}{|c|c|c|c|}
\hline Value & Class & $\begin{array}{c}\text { Frequently } \\
\text { level }\end{array}$ & $\begin{array}{c}\text { Criteria } \\
\text { (Pi: Probability of } \\
\text { occurrence) }\end{array}$ \\
\hline 5 & $\mathrm{~A}$ & Frequent & $\mathrm{Pi} \geq 0.2$ \\
\hline 4 & $\mathrm{~B}$ & Probable & $0.1 \leq \mathrm{Pi}<0.2$ \\
\hline 3 & $\mathrm{C}$ & Occasional & $0.01 \leq \mathrm{Pi}<0.1$ \\
\hline 2 & $\mathrm{D}$ & Remote & $0.001 \leq \mathrm{Pi}<0.01$ \\
\hline 1 & $\mathrm{E}$ & Improbable & $0 \leq \mathrm{Pi}<0.001$ \\
\hline
\end{tabular}

TABLE IV DETECTION CLASSIFICATION

\begin{tabular}{|c|c|c|}
\hline Value & Class & Criteria \\
\hline 1 & F & Good identification \\
\hline 2 & E & Fair identification \\
\hline 3 & D & $\begin{array}{c}\text { Good detection \& rough } \\
\text { identification }\end{array}$ \\
\hline 4 & C & Fair detection \\
\hline 5 & B & Rough detection \\
\hline 6 & A & Complementary test \\
\hline
\end{tabular}

\section{REFERENCES}

[1] "PAS 55 Asset Management", published by BSI, 2008

[2] IEC 60812, "Analysis technique for system reliability - procedure for failure mode and effects analysis (FMEA)", Second edition, 2006.

[3] S Jafarishiadeh, M Ardebili, A Nazari Marashi, "Investigation of pole and slot numbers in axial-flux pm bldc motors with singlelayer windings for electric vehicles," 24th Iranian Conference on Electrical Engineering (ICEE), pp. 1444-1448, 2016.

[4] Seyyedmahdi Jafari Shiadeh, Mohammad Ardebili, and Parvin Moamaei, "Three-dimensional finite-element-model investigation of axial-flux PM BLDC machines with similar pole and slot combination for electric vehicles", In: Proceedings of Power and Energy Conference, Illinois, pp. 1-4, 2015.

[5] H. Norouzi, S. Abedi, R. Jamalzadeh, M. Ghiasi Rad, S.H. Hosseinian, "Modeling and investigation of harmonic losses in optimal power flow and power system locational marginal pricing," Energy Journal, Science Direct, P-68 (2014) 140e147

[6] H. Jouybari Moghaddam, S.H. Hosseinian, B. Vahidi, M. Ghiasi Rad, "Smart Control mode selection for proper operation of synchronous distributed generators", 2nd Iranian Conference on Smart Grids, Iran (Islamic Republic of), 2012

[7] B. Kaztenny, G. Brunello, B. Kasztenny, C. Wester: "Shunt Capacitor Bank Fundamentals and Protection", Conference for Protective Relay Engineers-Texas A\&M University, 2003.

[8] M.A. El-Hadidy, D.H. Helmi: "Failure Analysis of Medium Voltage Capacitor Banks: The Egyptian Experience", CIRED 2009.

[9] "Transmission Baseline Study Report", Prepared for British Columbia Transmission Corporation by Acres International Ltd, Apr. 2005.

[10] Sarfi, V. and V. Hemmati. "Simulation of partial discharge in closely coupled cavities embedded in solid dielectrics by finite element method." In High Voltage Engineering and Application (ICHVE), 2014 International Conference on, pp. 1-4. IEEE, 2014. doi: 10.1109/ICHVE.2014.7035406

[11] M. Masoomi, N. Shamsaei, X. Gao, S. M. Thompson, A. Elwany, L. Bian, N. Shamsaei, L. Bian, and A. Elwany, "Modeling, simulation and experimental validation of heat transfer during selective laser melting," in ASME 2015 International Mechanical Engineering Congress \& Exposition, 2015. 


\section{ISO 3297:2007 Certified}

Vol. 5, Issue 2, February 2017

[12] M. Masoomi, S. M. Thompson, N. Shamsaei, A. Elwany, and L. Bian, "An Experimental-Numerical Investigation of Heat Transfer during Selective Laser Melting," in 26th International Solid Freeform Fabrication Symposium, 2015.

[13] P. Gharghabi, J. Lee, M. S. Mazzola, and T. E. Lacy Jr., "Development of an Experimental Setup to Analyze Carbon/Epoxy Composite Subjected to Current Impulses," Am. Soc. Compos. Thirty-First Tech. Conf., 2016.

[14] Sarfi, V., V. Hemmati, and M. M. Arabshahi. "Simulation of PTC devices as fault current limiters in power systems by finite element method." In High Voltage Engineering and Application (ICHVE), 2014 International Conference on, pp. 1-4. IEEE, 2014. doi: 10.1109/ICHVE.2014.7035503

[15] P. Gharghabi, P. Dordizadeh-Basirabad, and K. Niayesh, "Impact of Metal Thickness and Field Shaper on the Time-varying Processes during Impulse Electromagnetic Forming in Tubular Geometries,” J. Korean Phys. Soc., vol. 59, pp. 3560-3566, 2011.
[16] P. Dordizadeh-Basirabad, P. Gharghabi, and K. Niayesh, "Dynamic Analysis of a Fast-acting Circuit Breaker (Thompson) Drive Mechanism,” J. Korean Phys. Soc., vol. 59, pp. 3547-3554, 2011.

[17] R. Jalilzadeh Hamidi, S. H. Hosseinian, and S. H. H. Sadeghi, and Z. Qu, "A novel approach to utilize PLC to detect corroded and eroded segments of power transmission lines," IEEE Trans. Power Delivery, Vol. 30, No. 2, pp. 746-754, 2015.

[18] Khalili A., Samaratunga D., Jha R., Lacy T. E., Gopalakrishnan S. "WSFE-based User-Defined Elements in ABAQUS for Modeling 2D Laminated Composites with Complex Features" 30th ASC Technical Conference, Michigan State University, East Lansing, MI, US, 28-30 September 2015.

19] Khalili A., Samaratunga D., Jha R., Lacy T. E., Gopalakrishnan S. "Wavelet Spectral Finite Element Based User-Defined Element in Abaqus for Modeling Delamination in Composite Beams" 23rd AIAA/ASME/AHS Adaptive Structures Conference, Kissimmee, FL, US, 5-9 January 2015.

\section{TABLE V FMEA WORKSHEET PROVIDED FOR CAPACITOR BANKS USED IN OMAN DistribUTION POWER SYSTEM}

\begin{tabular}{|c|c|c|c|c|c|c|c|c|}
\hline \multirow{2}{*}{ 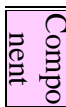 } & \multirow{2}{*}{. } & \multirow{2}{*}{$\begin{array}{l}\text { Failure } \\
\text { modes }\end{array}$} & \multirow{2}{*}{ Failure causes } & \multicolumn{2}{|c|}{ Failure effect } & \multirow{2}{*}{$\begin{array}{l}\text { Detection } \\
\text { method }\end{array}$} & \multirow{2}{*}{$\begin{array}{c}\text { Compensating } \\
\text { Provision }\end{array}$} & \multirow{2}{*}{ 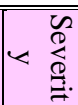 } \\
\hline & & & & Local Effect & Final Effect & & & \\
\hline \multirow{8}{*}{ 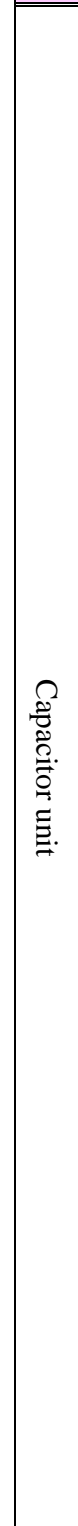 } & \multirow{8}{*}{ 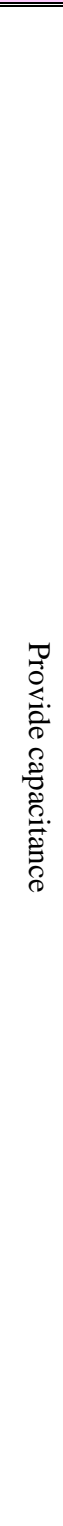 } & $\begin{array}{l}\text { Short } \\
\text { circuit }\end{array}$ & $\begin{array}{c}\text { A failure in the } \\
\text { capacitor element } \\
\text { dielectric causes the } \\
\text { foils to weld together }\end{array}$ & $\begin{array}{l}\text { Blown relative } \\
\text { fuse / Change in } \\
\text { capacitance / } \\
\text { Slightly higher } \\
\text { voltage across } \\
\text { other series } \\
\text { capacitors }\end{array}$ & \multirow{3}{*}{$\begin{array}{l}\text { Probability } \\
\text { of unbalance } \\
\text { relay trip }\end{array}$} & \multirow{3}{*}{$\begin{array}{l}\text { Measuring } \\
\text { capacitance } \\
\text { value of unit } \\
\text { from bushing }\end{array}$} & $\begin{array}{l}\text { Replace capacitor unit } \\
\text { after unbalance relay } \\
\text { trip / repair unit and } \\
\text { change short element }\end{array}$ & II \\
\hline & & $\begin{array}{l}\text { Open } \\
\text { circuit }\end{array}$ & $\begin{array}{l}\text { Disconnection of any } \\
\text { interconnecting wires }\end{array}$ & \multirow{2}{*}{$\begin{array}{l}\text { Change in } \\
\text { capacitance }\end{array}$} & & & $\begin{array}{c}\text { Replace capacitor unit } \\
\text { after unbalance relay } \\
\text { trip / repair unit and } \\
\text { connect any } \\
\text { disconnection } \\
\end{array}$ & II \\
\hline & & $\begin{array}{l}\text { Fuse } \\
\text { failure }\end{array}$ & $\begin{array}{c}\text { Failure of seals and } \\
\text { ingress of moisture / } \\
\text { environment high } \\
\text { temperature } \\
\end{array}$ & & & & $\begin{array}{l}\text { Replace capacitor unit } \\
\text { after unbalance relay } \\
\text { trip / repair unit and } \\
\text { change failure fuses }\end{array}$ & II \\
\hline & & $\begin{array}{l}\text { Insulating } \\
\text { liquid } \\
\text { leakage }\end{array}$ & $\begin{array}{l}\text { Wearing of metal } \\
\text { enclosure of the unit, } \\
\text { any gap or seam of } \\
\text { the enclosure }\end{array}$ & $\begin{array}{l}\text { Decreasing } \\
\text { insulator liquid }\end{array}$ & $\begin{array}{l}\text { Probability } \\
\text { of change in } \\
\text { capacitance }\end{array}$ & Visual check & $\begin{array}{c}\text { Use adhesive material } \\
\text { / soldering }\end{array}$ & II \\
\hline & & $\begin{array}{c}\text { Bushing } \\
\text { degradatio } \\
\text { n (include } \\
\text { cracking, } \\
\text { wear \& } \\
\text { contaminat } \\
\text { ion) }\end{array}$ & $\begin{array}{l}\text { Insulation failure / } \\
\text { external } \\
\text { contamination } \\
\text { / moisture }\end{array}$ & $\begin{array}{c}\text { Partial } \\
\text { discharge on the } \\
\text { external surface } \\
\text { of insulation / } \\
\text { flashover }\end{array}$ & $\begin{array}{l}\text { short circuit } \\
\text { / personal } \\
\text { safety / } \\
\text { enclosure } \\
\text { rupture or } \\
\text { explosion }\end{array}$ & $\begin{array}{l}\text { Power factor of } \\
\text { bushing / tan } \\
\text { delta / Visual } \\
\text { check }\end{array}$ & $\begin{array}{l}\text { Routine inspection } \\
\text { such as cleaning / } \\
\text { replace bushing }\end{array}$ & II \\
\hline & & $\begin{array}{l}\text { Thermal } \\
\text { stresses }\end{array}$ & $\begin{array}{l}\text { Environment high } \\
\text { temperature }\end{array}$ & $\begin{array}{l}\text { Cumulative and } \\
\text { non-reversible } \\
\text { degradation of }\end{array}$ & Degradation & $\begin{array}{l}\text { Check the } \\
\text { environment } \\
\text { temperature }\end{array}$ & $\begin{array}{c}\text { Replace capacitor unit } \\
\text { with one with high } \\
\text { permissible } \\
\text { temperature }\end{array}$ & III \\
\hline & & $\begin{array}{l}\text { Electrical } \\
\text { stresses }\end{array}$ & $\begin{array}{l}\text { Steady state, transient } \\
\text { and dynamic over } \\
\text { voltage condition }\end{array}$ & $\begin{array}{l}\text { insulation in } \\
\text { capacitor units } \\
\text { and external } \\
\text { insulators }\end{array}$ & $\begin{array}{l}\text { capacitor } \\
\text { unit }\end{array}$ & $\begin{array}{c}\text { Test insulation } \\
\text { (Partial } \\
\text { Discharge, } \\
\text { tan delta)/ } \\
\text { Check records }\end{array}$ & Replace capacitor unit & III \\
\hline & & $\begin{array}{l}\text { Fail to } \\
\text { provide } \\
\text { safety in } \\
\text { operation }\end{array}$ & Interlock failure & $\begin{array}{l}\text { Operation } \\
\text { without } \\
\text { checking the } \\
\text { interlock }\end{array}$ & $\begin{array}{l}\text { Over voltage } \\
\text { / Damage of } \\
\text { capacitor } \\
\text { bank / } \\
\text { personal } \\
\text { safety }\end{array}$ & $\begin{array}{l}\text { Check control } \\
\text { supply } \\
\text { supervision } \\
\text { alarm }\end{array}$ & $\begin{array}{c}\text { Check control wiring } \\
\text { by buzzer test, find } \\
\text { problem and fix it }\end{array}$ & IV \\
\hline
\end{tabular}


IJIREEICE

International Journal of Innovative Research in Electrical, Electronics, Instrumentation and Control Engineering

ISO 3297:2007 Certified

Vol. 5, Issue 2, February 2017

\begin{tabular}{|c|c|c|c|c|c|c|c|c|}
\hline \multirow{2}{*}{ 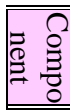 } & \multirow{2}{*}{ 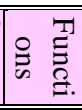 } & \multirow{2}{*}{$\begin{array}{l}\text { Failure } \\
\text { modes }\end{array}$} & \multirow{2}{*}{ Failure causes } & \multicolumn{2}{|c|}{ Failure effect } & \multirow{2}{*}{$\begin{array}{c}\text { Detection } \\
\text { method }\end{array}$} & \multirow{2}{*}{$\begin{array}{c}\text { Compensating } \\
\text { Provision }\end{array}$} & \multirow{2}{*}{ 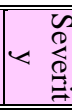 } \\
\hline & & & & Local Effect & Final Effect & & & \\
\hline \multirow{3}{*}{ 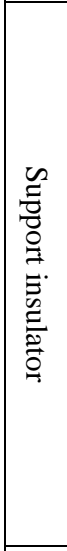 } & \multirow{3}{*}{ 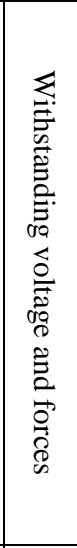 } & $\begin{array}{l}\text { Electrical } \\
\text { flash over }\end{array}$ & $\begin{array}{c}\text { Ionized air/ } \\
\text { contaminated air / } \\
\text { electrical over } \\
\text { voltages }\end{array}$ & $\begin{array}{l}\text { Flash over / } \\
\text { short circuit }\end{array}$ & $\begin{array}{l}\text { Equipment } \\
\text { damage/ } \\
\text { hazard to } \\
\text { personnel }\end{array}$ & $\begin{array}{c}\text { Partial } \\
\text { discharge/ } \\
\text { Power system } \\
\text { disturbance } \\
\text { recorder } \\
\end{array}$ & $\begin{array}{l}\text { Visual inspection/ } \\
\text { cleaning / } \\
\text { partial discharge }\end{array}$ & IV \\
\hline & & $\begin{array}{l}\text { Leakage } \\
\text { current }\end{array}$ & $\begin{array}{c}\text { Contaminated surface } \\
\text { / Tracks }\end{array}$ & Leakage current & \multirow{2}{*}{$\begin{array}{l}\text { Short circuit/ } \\
\text { Equipment } \\
\text { damage }\end{array}$} & \multirow{2}{*}{$\begin{array}{l}\text { visual } \\
\text { inspection/ } \\
\text { Partial } \\
\text { discharge/ } \\
\text { thermograph } \\
\text { inspection }\end{array}$} & $\begin{array}{l}\text { Visual inspection/ } \\
\text { cleaning /partial } \\
\text { discharge/ } \\
\text { thermograph } \\
\text { inspection } \\
\end{array}$ & III \\
\hline & & $\begin{array}{l}\text { Thermal } \\
\text { effects and } \\
\text { electromec } \\
\text { hanical } \\
\text { forces }\end{array}$ & Excessive currents & $\begin{array}{l}\text { Insulator } \\
\text { Damage }\end{array}$ & & & $\begin{array}{l}\text { Periodic review of } \\
\text { system fault levels/ } \\
\text { Power system } \\
\text { disturbance recorder }\end{array}$ & III \\
\hline \multirow{7}{*}{ ఫ્ટ } & \multirow{7}{*}{ 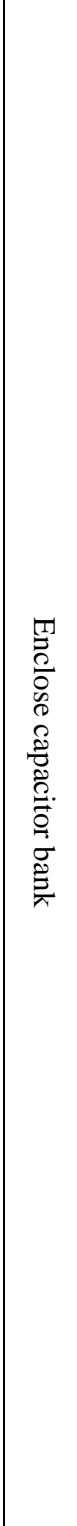 } & $\begin{array}{l}\text { misaligned } \\
\text { and failure } \\
\text { of } \\
\text { mounting }\end{array}$ & $\begin{array}{c}\text { Panel misplacement / } \\
\text { displacement }\end{array}$ & $\begin{array}{l}\text { Stress on } \\
\text { insulator and } \\
\text { bushings and } \\
\text { other capacitor } \\
\text { components }\end{array}$ & $\begin{array}{l}\text { Failure of } \\
\text { insulator, } \\
\text { bushings and } \\
\text { other } \\
\text { capacitor } \\
\text { components }\end{array}$ & \multirow{3}{*}{$\begin{array}{c}\text { Visual } \\
\text { inspection }\end{array}$} & Re-install the panel & II \\
\hline & & $\begin{array}{c}\text { Degradatio } \\
\mathrm{n} \text { of panel } \\
\text { body plate } \\
\text { (Corrosion } \\
\text {, damage, } \\
\text { fatigue, } \\
\text { rust spots, } \\
\text { graffiti \& } \\
\text { scratch) } \\
\end{array}$ & $\begin{array}{l}\text { Impact, degradation } \\
\text { over the time, } \\
\text { environment } \\
\text { condition (such as } \\
\text { salt spray in coastal } \\
\text { areas), etc. }\end{array}$ & $\begin{array}{l}\text { Failure of body } \\
\text { of panel / Plate } \\
\text { corrosion and } \\
\text { degradation / } \\
\text { failure of IP }\end{array}$ & \multirow{2}{*}{$\begin{array}{l}\text { Probability } \\
\text { of damage of } \\
\text { internal } \\
\text { component } \\
\text { of panel }\end{array}$} & & $\begin{array}{l}\text { Routine maintenance / } \\
\text { replace the panel }\end{array}$ & II \\
\hline & & $\begin{array}{l}\text { Failure of } \\
\text { protection } \\
\text { degree of } \\
\text { panel (IP) }\end{array}$ & $\begin{array}{l}\text { degradation over the } \\
\text { time, degradation or } \\
\text { loosening sealed } \\
\text { materials and } \\
\text { degradation of seal of } \\
\text { cable entrances }\end{array}$ & $\begin{array}{l}\text { Ingress of dust } \\
\text { and water }\end{array}$ & & & Routine maintenance & II \\
\hline & & \multirow{2}{*}{$\begin{array}{l}\text { Failure of } \\
\text { lighting / } \\
\text { heater / } \\
\text { thermostat } \\
\text { of panel (if } \\
\text { exist) }\end{array}$} & \multirow{2}{*}{$\begin{array}{l}\text { Degradation over the } \\
\text { time / impact / failure } \\
\text { of relative circuit } \\
\text { (disconnection, } \\
\text { loosening, burning) }\end{array}$} & $\begin{array}{l}\text { Difficulty of } \\
\text { personnel for } \\
\text { any necessary } \\
\text { operation or } \\
\text { inspection }\end{array}$ & $\begin{array}{l}\text { Personnel } \\
\text { safety }\end{array}$ & $\begin{array}{c}\text { Visual } \\
\text { inspection }\end{array}$ & \multirow{3}{*}{$\begin{array}{l}\text { Routine maintenance / } \\
\text { replace the panel }\end{array}$} & \multirow[t]{2}{*}{ II } \\
\hline & & & & $\begin{array}{c}\text { Heater / } \\
\text { thermostat / } \\
\text { Moisture } \\
\text { ingress } \\
\end{array}$ & \multirow[b]{2}{*}{$\begin{array}{l}\text { Probability } \\
\text { of damage of } \\
\text { internal } \\
\text { component } \\
\text { of panel }\end{array}$} & Functional test & & \\
\hline & & $\begin{array}{c}\text { Failure of } \\
\text { door to } \\
\text { operate } \\
\text { properly } \\
\text { (open, } \\
\text { close, } \\
\text { lock) }\end{array}$ & $\begin{array}{l}\text { Degradation over the } \\
\text { time / panel } \\
\text { displacement / impact }\end{array}$ & $\begin{array}{l}\text { Difficulty of } \\
\text { personnel / } \\
\text { failure of IP }\end{array}$ & & $\begin{array}{c}\text { Visual } \\
\text { inspection / test }\end{array}$ & & II \\
\hline & & $\begin{array}{l}\text { Disconnect } \\
\text { ion of } \\
\text { electrical } \\
\text { connection } \\
\text { s or wiring } \\
\end{array}$ & $\begin{array}{c}\text { Impact / loosening of } \\
\text { connection / design } \\
\text { and installation } \\
\text { mistakes }\end{array}$ & $\begin{array}{l}\text { Disconnecting } \\
\text { the circuit }\end{array}$ & $\begin{array}{l}\text { Disconnectin } \\
\text { g capacitor } \\
\text { bank }\end{array}$ & $\begin{array}{c}\text { Functional test } \\
\text { buzzer test }\end{array}$ & $\begin{array}{l}\text { Find disconnection } \\
\text { and fix it }\end{array}$ & II \\
\hline
\end{tabular}

